\title{
Antibacterial activity of the dregs of green tea leaves (Camellia sinensis L.) on Staphylococcus epidermidis as causes of acne
}

\author{
Naniek Widyaningrum ${ }^{1 *}$, Badie'ah $^{2}$, Sri Lestari $^{1}$ \\ ${ }^{1}$ Pharmacy Program, Faculty of Medicine, Sultan Agung Islamic University, Semarang \\ ${ }^{2}$ Faculty of Industrial Technology, Sultan Agung Islamic University, Semarang
}

\begin{abstract}
The dregs of green tea leaves have not been used until today, it is still considered as a waste that is not useful. It is known that the dregs of the green tea leaves contain Epigallocatechin-3gallate (EGCG), which is quite high. EGCG has benefits as an antibacterial. The long-term goal of this research is the application of cosmetic preparation products from the dregs of green tea leaves that have effectiveness, stability and high economic value. The specific target of this research is to get the dose and concentration of the dregs of green tea leaves in a stable and effective way as anti-acne against Staphylococcus epidermidis (S. epidermidis). The search of the dregs of green tea leaves is by techniques of infundation of liquid fractions with ethyl acetate, identification of EGCG compound by using HPLC, antibiotics test against S. epidermidis was conducted by diffusion method. The results showed that the content of EGCG of the dregs of green tea leaves was $21.325 \% \mathrm{w} / \mathrm{w}$, and the concentration of $1 \%$ of the dregs of green tea leaves can inhibit the growth of $S$. epidermidis well.
\end{abstract}

Keywords: Epigallocatechin-3-gallate (EGCG), green tea leaves dregs, S. epidermidis

Received: July 10, 2017; Accepted: September 7, 2017; Published online: October 23, 2017

*Corresponding author: naniek@unissula.ac.id

Citation: Widyaningrum, N., Badie'ah, \& Lestari, S. (2017). Antibacterial activity of the dregs of green tea leaves (Camellia sinensis L.) on Staphylococcus epidermidis as causes of acne. Journal of Science and Science Education, 1(2), 1-5.

\section{Introduction}

The prevalence of acne in adolescents and adults now reaches $85 \%$ whereas in pregnant women in France reaches $42.3 \%$ based on the number of pregnant women who consulted to dermatologist. Meanwhile, the prevalence of pregnant women in Asia is not known. Treatment of acne at various ages and pregnant women until today is still limited to the use of antibiotics that can cause resistance. Erythromycin and Clindamycin antibiotics can cause bacterial resistance of Propionibacterium acnes (P. acnes) (Leyden et al., 2011). Erythromycin is the first line of acne therapy in pregnant women and other antibiotics which can cause resistance to $P$. acnes bacteria. To overcome such resistance is by using higher doses of antibiotics in concern. The occurrence of antibiotic resistance in topical use in the world up to $94 \%$. Antibiotic treatment given to pregnant women often has an impact on fetal safety. Topical retinoids in pregnancy was feared to cause systemic absorption which can cause fetal teratogenic. Tetracycline group as the first line of acne treatment is also avoided as unsafe for fetal growth in the first half of the third semester of pregnancy (Kubba et al., 2009).

Epigallocatechin gallate (EGCG) in the dreg of green tea leaf is known to have antibacterial activity. EGCG also can kill the Acinetobacter baumani bacteria that are resistant to antibiotics. 
According to Widyaningrum et al. (2012) ethanolic extract of green tea leaves in the standard formula preparations cream of $7 \%$ had the same efficacy with acne Ristra cream ${ }^{\circledR}$ in inhibiting the activity of Staphylococcus aureus (S. aureus). The research of Widyaningrum et al. (2015a) also stated that ethyl acetate fraction of green tea leaf extract concentration of $1 \%$ to $6 \%$ has antibacterial activity on $P$. acnes and Staphylococcus epidermidis (S. epidermidis). The concentration of $6 \%$ is recommended as a dose concentration of anti-acne. This suggests that EGCG on green tea leaves can be used as an alternative to acne treatment.

The dregs of green tea leaves until now has not been utilized, it is still considered as a waste that is not useful. Utilization of green tea dreg as anti-acne has not been reported.

\section{Materials and Methods}

This research consist of 3 stages, that is manufacture of the dregs extract of green tea leaves, identification of EGCG from the dregs of Green tea, and antibacterial test activity of S. epidermidis on fraction ethyl acetate of the dregs of green tea leaves by concentration of $1 \%$ to $6 \%$.

\subsection{Research methods}

\subsubsection{Collecting the dregs of green tea leaves and fractionation}

The waste of the dregs of green tea leaves was obtained from PT. Sari Kemuning, Karang Anyar (Widyaningrum et al., 2015b). The waste was then extracted and fractionated.

\subsubsection{Extraction and fractination}

It was done with infundation method by using distilled water with a temperature of $90^{\circ} \mathrm{C}$ for 30 minutes, then an extreme cold and the addition of Dapar solution to $\mathrm{pH} 4$ were performed (Widyaningrum et al., 2015a).

Fractionation: it was performed by adding 1:1 ethyl acetate in separating funnel, then the water phase was discarded, and such ethyl acetate phase was evaporated with a rotary evaporator until it became dry powder.

\subsubsection{Ethyl acetate fraction specification of the dregs of green tea leaves extract}

This was performed by using methods by Martono \& Martono (2012), which reversed-phase HPLC with isocratic elution system. The mobile phase used $0.1 \%$ phosphoric acid mixture: methanol: acetonitrile: aquabidest at a ratio of 14:1:3: $7(\mathrm{v} / \mathrm{v} / \mathrm{v} / \mathrm{v})$. The previously used distilled water was filtered. After four mixed then tri ethylamine was added until a $\mathrm{pH} 4$ was obtained. The sample was injected with $20 \mu \mathrm{l}$ injection volume which then eluted by using a silent face $C 18$, a flow rate of 1.2 $\mathrm{ml} / \mathrm{min}$ and detected by UV detector at $\lambda 280 \mathrm{~nm}$.

\subsubsection{The antibacterial activity}

S. epidermidis ATCC 35984 were incubated in media for 24 hours under aerobic conditions at $37^{\circ} \mathrm{C}$. Then, the suspension of bacteria by using sterile $0.9 \% \mathrm{NaCl}$ was made. A sterile cotton lid was inserted into a tube containing bacteria, then pressed on the tube wall so as not too wet. The cotton then was swabbed on Mueller Hinton media that had previously been incubated for approximately 2 hours until smooth and thin as possible, then a hole on Mueller Hinton medium was created. The 
fraction by concentration of $6 \%$ was inserted into the plate hole which then incubated at $37^{\circ} \mathrm{C}$ for 24 hours in aerobic conditions (Niyomkam et al., 2010).

\section{Results and Discussion}

Acne is a skin disease suffered swelling (abscesses) on the surface, where the oil-producing glands were clogged and contaminated by bacteria. The bacteria that cause acne is Propionibacterium acnes, Streptococcus epidermidis, etc. (Mahmood et al., 2010). Anti-acne activity in green tea has been shown to be potential in inhibiting $P$. acnes, but studies that test anti-acne in green tea leaf dregs have not been reported until today.

Green tea is a tea which in the process of making it does not experience fermentation. Gynecology EGCG in green tea leaves ranges from $60 \% \mathrm{w} / \mathrm{w}$ (Widyaningrum et al., 2015b), if compared with the number of dregs of the green tea leaves in this study which was $21.325 \% \mathrm{w} / \mathrm{w}$ (Table 1 ). The dregs of green tea leaves could still be utilized as a preparation which has the effectiveness. It is expected that with the basic ingredients of green tea leaf, it can be an alternative preparation with a more economical price given the price of pure EGCG is quite high.

The high content of EGCG in green tea leaf dregs may have activity as anti-acne. Mechanism of Epigallocatechin-3-gallate ( $E G C G$ ) as an anti-acne is suppress inflammatory activity that occurs through NF-kB and AP-1 in order to reduce the survival of $P$. acnes and S.epidermidis as the cause of acne bacteria (Mahmood et al., 2010). The results of antibacterial activity of green tea leaves leaf against $S$. epidermidis are presented in Figure 1 and Table 2.

Table 1. Concentrations of EGCG in green tea leaves dregs.

\begin{tabular}{cc}
\hline Replication & EGCG\% w/w \\
\hline 1 & 20.48 \\
2 & 22.17 \\
Average & 21.33 \\
\hline
\end{tabular}

Table 2. Zones of inhibition results of antibacterial $(\mathrm{mm})$.

\begin{tabular}{|c|c|c|c|c|c|c|c|c|}
\hline \multirow{2}{*}{ Replication } & \multicolumn{6}{|c|}{ Zones of inhibition results (mm) } & \multirow{2}{*}{$\begin{array}{l}\text { Aquades } \\
\text { t control }\end{array}$} & \multirow{2}{*}{$\begin{array}{c}\text { Tetracycline } \\
\text { control }\end{array}$} \\
\hline & $1 \%$ & $2 \%$ & $3 \%$ & $4 \%$ & $5 \%$ & $6 \%$ & & \\
\hline 1 & 20 & 27 & 28 & 28 & 30 & 30 & 0 & 15 \\
\hline 2 & 20 & 27 & 28 & 28 & 30 & 30 & 0 & 15 \\
\hline 3 & 20 & 26.5 & 27.5 & 29 & 30 & 30 & 0 & 15 \\
\hline Average $\pm S D$ & $20 \pm 0$ & $26.83 \pm 0.28$ & $27.83 \pm 0.28$ & $28.33 \pm 0.57$ & $30 \pm 0$ & $30 \pm 0$ & $0 \pm 0$ & $15 \pm 0$ \\
\hline
\end{tabular}

Based on the antibacterial activity of S. epidermidis test of the dregs of green tea leaves in our study, it proved that the dregs leaf green tea has anti-acne activity at a concentration of $1 \%$ in inhibiting the survival of $S$. epidermidis. These results are consistent with research by Widyaningrum et al. (2015a) which stated ethyl acetate fraction of green tea leaf extract concentration of $1 \%$ to $6 \%$ have antibacterial activity on $P$. acnes and S. epidermidis and concentration of 1 to $9 \%$ have antibacterial activity on Staphylococcus aureus (Widyaningrum, 2013), so the concentration of $1 \%$ is recommended as a dose concentration of anti acne. This shows that the leaves of green tea leaves can be used as an alternative in overcoming acne. 

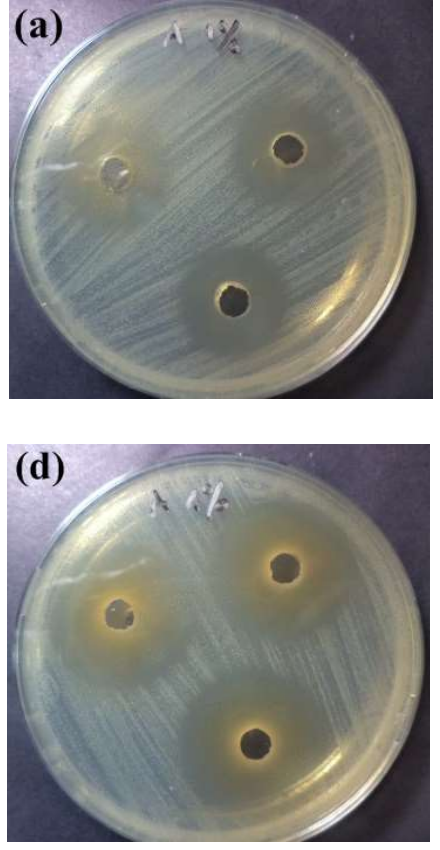

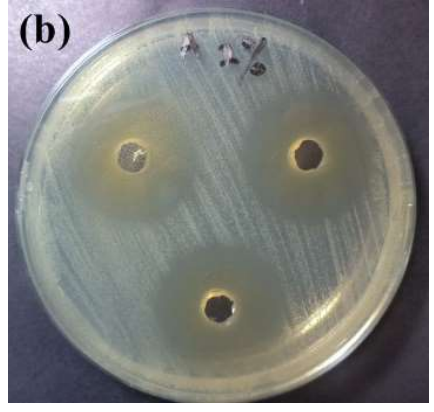

(e)

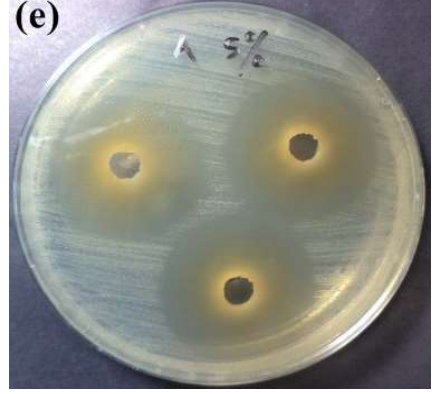

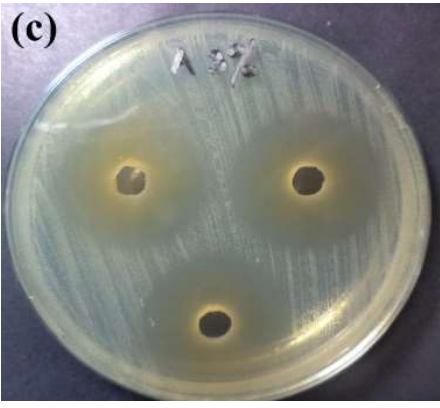

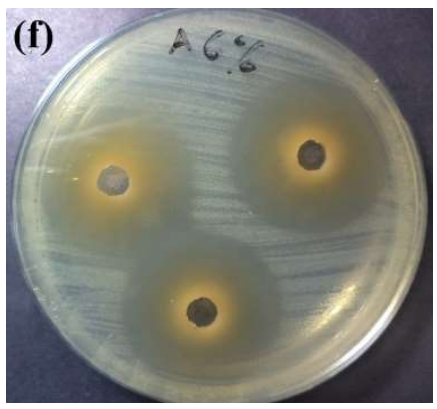

Figure 1. Staphylococcus epidermidis inhibition of concentration of: (a) $1 \%$, (b) $2 \%$, (c) $3 \%$, (d) $4 \%$, (e) $5 \%$, and (f) $6 \%$.

\section{Conclusion and Remarks}

The dregs of green tea leaves still contain high EGCG and has anti acne activity. Based on the antibacterial activity of $S$. epidermidis test on the dregs of green tea leaves in our study, it was obtained that the dregs of green tea leaves have anti-acne activity at a concentration of $1 \%$ which is as a recommended dose. The dregs of the green tea leaves can be used as an alternative treatment of acne.

\section{Acknowledgment}

- Thanks to RISTEKDIKTI who has provided research funding.

- Thanks to the LPPM of Unissula which has helped in the process of RISTEKDIKTI Grants.

- Thanks to the Pharmacy Program of Unissula and Microbiology laboratories of Medicine Faculty UGM for laboratory support.

\section{References}

Kubba, R., Bajaj, A. K., Thappa, D. M., Sharma, R., Vedamurthy, M., \& Dhar, S., ... Thomas, J. (2009). Acne in India: Guidelines for management - IAA consensus document. Indian J. Dermatol. Venereol. Leprol., 75 Suppl. 1, 1-62.

Leyden, J. J., Preston, N., Osborn, C., \& Gottschalk, R. W (2011). In-vivo effectiveness of adapalene $0.1 \% /$ benzoyl peroxide $2.5 \% \mathrm{Gel}$ on antibiotic-sensitive and resistant Propionibacterium acnes. J. Clin. Aesthetic Dermatol, 4(5), 22-26.

Mahmood, T., Akhtar, N., Khan, B. A., Khan, H. M., \& Saeed, T. (2010). Outcomes of 3\% green tea emulsion on skin sebum production in male volunteers. Bosn. J. Basic Med. Sci, 10(3), 260-264. 
Martono, Y., \& Martono, S (2012). Analisis kromatografi cair kinerja tinggi untuk penetapan kadar asam galat, kafein dan epigalokatekin galat pada beberapa produk teh celup. Agritech, 32(4), 362-369.

Niyomkam, P., Kaewbumrung, S., Kaewnpparat, S., \& Panichayupakaranant, P. (2010). Antibacterial activity of Thai herbal extracts on acne involved microorganism. Pharm. Biol, 48(4), 375-380.

Widyaningrum, N., Murrukmihadi, M., \& Ekawati, S. K. (2012). Pengaruh konsentrasi ekstrak etanolik daun teh hijau (Camellia sinesis L.) dalam sediaan krim terhadap sifat fisik dan aktivitas antibakteri. Jurnal Sains Medika, 4, 147-156.

Widyaningrum, N., Fuholi, A., Sudarsono, Setyowati, E. P. (2015a). The stability of Epigallocatechin gallate (EGCG) from green tea (Camellia Sinensis) and its antibacterial activity against Staphylococcus Epidermidis ATCC 35984 and Propionibacterium acnes ATCC 6919. Asian. J. of Biol. Sci, 8(2), 93-101.

Widyaningrum, N., Fuholi, A., Sudarsono, Setyowati, E. P. (2015b). The effect of altitude against total phenolic and Epigallocatechin Gallate (EGCG) content in green tea leaves. In F. S. Rondonuwu, A. Setiawan, L. N. Lestario, H. A. Parhusip., T. Mahatma, \& D. B. Nugroho (Eds.), Proceedings of the 2015 International Conference on Science and Science Education (pp. BC34-40). Salatiga, SWUP.

Widyaningrum, N. (2013). Epigallocatechin-3-Gallate (EGCG) on green tea as antiacne. Majalah Farmasi dan Farmakologi, 17(3), 95-98. 